\title{
Investigation of unfired Bricks Prepared by Shangluo Molybdenum tailings
}

\author{
Chunsheng Zhou ${ }^{\mathrm{a}}$, Chun $\mathrm{Li}^{\mathrm{b}}$,Le Cui ${ }^{\mathrm{c}}$, Guochun Zhang ${ }^{\mathrm{d}}$, xiaowei Cui ${ }^{\mathrm{e}}$, \\ (Shaanxi Key Laboratory of Comprehensive Utilization of Tailings Resources, Shangluo \\ University,Shangluo 72600, China) \\ aemail:slzhousc@126.com, bemail:lic_slxy@163.com, email:cuile_slxy@163.com, \\ demail:1069969692@qq.com, eemail:zgc326@126.com
}

Keywords: Molybdenum tailings; unfired Bricks; Flexural strength; Compressive strength

Abstract.Using molybdenum tailings in Shangluo as a core sample and the cement as gelled material, the unfired brick is prepared by mixing molybdenum tailings, cement, sand, silica powder and accelerating admixture, and then stirring and vibration. The effects of molybdenum tailings content, the ratio of molybdenum tailings to river sand and the addition of the silica powder on mechanical properties of the unfired brick. Results show that With the addition of molybdenum tailings increased, the mechanical properties of the unfired brick was decreased. When the addition of molybdenum tailings is below 75\%, the flexural strength and compressive strengh are above 4.83MPa and 15.69MPa respectively, it meets MU15 standard. With the ratio molybdenum tailings to river sand increasing, the mechanical properties decreased firstly, and then increased. The mechanical properties of unfired brick is decreased with increasing of the silica powder.

\section{Introduction}

Entered the new century, a large of solid waste(e.g. taillings, slags, sluges, et al) are stockpiled, so that not only occupied over land and seriously polluted environment, but also the useful components of th tailings can not be fully utilized, resulting in a waste of resources ${ }^{[1]}$. And while the lives and property of the people are seriously threated. Shangluo tailings resources accounte for $1 \%$ of the country and one third of the province. Hence, it is great significance with using Shangluo tailings resources to develop recycling economy.

At present, every country carry out extensive research which work on the comprehensive utilization of the tailings by investing a lot of people, material and financial resource. The results show that Hanxing tailings can be used to produce building bricks with the standard number higher than MU10 by pressing method by Yin Hongfeng ${ }^{[2]}$. The unit weight and compressive strength of the lightweight baking-free brick prepared by different ratio of raw material and maintenance condition were studied by Feng Qiming ${ }^{[3]}$. And results show the dry bulk weight of lightweight baking-free brick was only as much as $2 / 3$ of solid shale brick, but the compressive strength was up to $9.3 \mathrm{MPa}$ when the mass percent of copper mine tailings was $70 \%$ to $80 \%$. The unfired bricks prepared with municipal sludge were studied by Yu Yanzhen ${ }^{[4]}$. It show that when the mass percent of the silt of the Yellow river, coal gangue, municipal sludge, grain slag, cement are $6 \mathrm{wt} \%$, 4wt $\%$, 30wt $\%$, 50wt $\%$, and $10 \mathrm{wt} \%$ respectively, the best bricks with $30.82 \mathrm{MPa}$ compressive strength. Therefore, in this work, the effect of the addition of molybdenum tailings and silica powder, and the ratio of molybdenum tailings to river sand on mechanical properties of unfired bricks were investigated. 


\section{Experimental and Materials}

\section{Molybdenum tailing}

This experiment used molybdenum tailing from Jiulong company, and its chemical composition is showed in table 1.

Table 1 Chemical composition of molybdenum tailing

\begin{tabular}{|c|c|c|c|c|c|c|c|c|c|c|c|c|}
\hline $\begin{array}{l}\text { chemical } \\
\text { composition }\end{array}$ & $\mathrm{SiO}_{2}$ & $\mathrm{Al}_{2} \mathrm{O}_{3}$ & $\mathrm{Fe}_{2} \mathrm{O}_{3}$ & $\mathrm{MgO}$ & $\mathrm{CaO}$ & $\mathrm{Na}_{2} \mathrm{O}$ & $\mathrm{K}_{2} \mathrm{O}$ & $\mathrm{TiO}_{2}$ & $\mathrm{P}_{2} \mathrm{O}_{5}$ & $\mathrm{MnO}$ & $\mathrm{SO}_{3}$ & $\begin{array}{l}\text { Loss on } \\
\text { ignition }\end{array}$ \\
\hline Content $/ \%$ & 72.38 & 3.88 & 9.19 & 1.08 & 2.25 & 0.27 & 1.93 & 1.06 & 0.13 & 0.22 & 5.00 & 2.56 \\
\hline
\end{tabular}

cement, Accelerating admixture and water

The cement is Qinling P.Q. 32.5R, its chemical composition is showed in table 2. The accelerating admixture is PC which is carboxylic acid polymers. The water is from local tap water.

Table 2 Chemical composition of cement

\begin{tabular}{cccccccc}
\hline Chemical composition & $\mathrm{SiO}_{2}$ & $\mathrm{Al}_{2} \mathrm{O}_{3}$ & $\mathrm{Fe}_{2} \mathrm{O}_{3}$ & $\mathrm{MgO}$ & $\mathrm{CaO}$ & $\mathrm{SO}_{3}$ & Loss on ignition \\
\hline Content $/ \%$ & 20.38 & 6.01 & 3.39 & 2.37 & 63.81 & 2.48 & $\sim$ \\
\hline
\end{tabular}

experimental process

Fig. 1 shows technical flowsheet of unburned brick. Molybdenum tailings, cement, river sand and silica powder were calculated and dry mixed for $2 \mathrm{~min}$. And then dry power raw material was added the water and wet mixed for $2 \mathrm{~min}$. Accelerating admixture was added and stirred. The raw material which were mixed uniformly was poured into steel mould which is $160 \mathrm{~mm} \times 40 \mathrm{~mm} \times 40 \mathrm{~mm}$, and then were maintained in the curing box. After $3 \mathrm{~d}, 7 \mathrm{~d}$ and $28 \mathrm{~d}$, mechanical properties of unburned brick were tested by universal testing machine and bending machine.

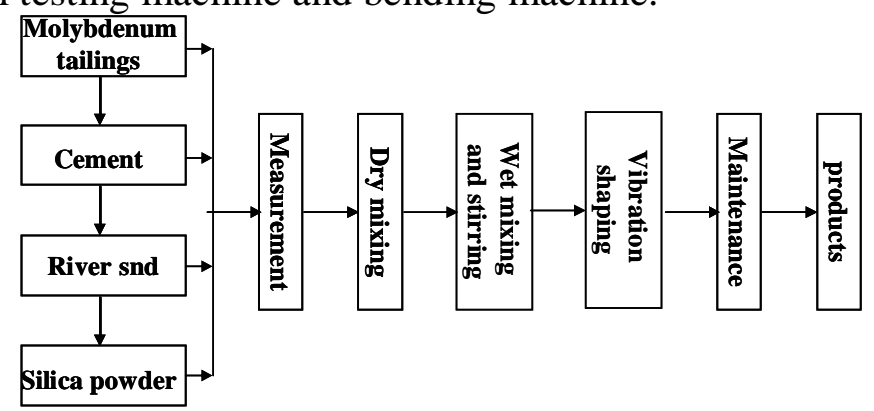

Fig.1 Technical flowsheet of unburned brick

\section{Results and Discussion}

The effect of the addition of molybdenum tailings on the properties of Baking-free Bricks

Table 3 and fig. 2 show the effect of molybdenum tailing on flexural strength and compressive strength of unfired brick at the different molybdenum tailings content. With increasing molybdenum tailings, flexural strength and comprehensive strength of the unfired brick were decreased. Meanwile, with curing time prolonging, the mechanical properties of unfired brick was increased. When curing time is $7 \mathrm{~d}$, the mechanical properties of unfired brick attained $80 \%$ which is the final.

Table 3. Experimental results of the addition of molybdenum tailings

\begin{tabular}{|c|c|c|c|c|c|c|c|c|c|}
\hline \multicolumn{3}{|c|}{ The ratio of dry solids } & \multirow{2}{*}{$\begin{array}{c}\text { Water } \\
\text { addition for } \\
\text { mixing/\% }\end{array}$} & \multicolumn{2}{|c|}{$\begin{array}{l}\text { 3d mechanical } \\
\text { properties/MPa }\end{array}$} & \multicolumn{2}{|c|}{$\begin{array}{l}7 \mathrm{~d} \text { mechanical } \\
\text { properties/MPa }\end{array}$} & \multicolumn{2}{|c|}{$\begin{array}{l}\text { 28d mechanical } \\
\text { properties/MPa }\end{array}$} \\
\hline $\begin{array}{c}\text { Molybden- } \\
\text { um tailings/ } \\
\%\end{array}$ & $\begin{array}{c}\text { Cement } \\
\text { amount } / \\
\%\end{array}$ & $\begin{array}{l}\text { Accelerating } \\
\text { Admixture/\% }\end{array}$ & & $\begin{array}{l}\text { Flexural } \\
\text { strength }\end{array}$ & $\begin{array}{l}\text { Compr-e } \\
\text { ssive } \\
\text { strength }\end{array}$ & $\begin{array}{l}\text { Flexural } \\
\text { strength }\end{array}$ & $\begin{array}{l}\text { Compres } \\
\text { sive } \\
\text { strength }\end{array}$ & $\begin{array}{l}\text { Flexural } \\
\text { strength }\end{array}$ & $\begin{array}{l}\text { Compr-e } \\
\text { ssive } \\
\text { strength }\end{array}$ \\
\hline 55 & 44 & 1 & 15 & 3.35 & 10.86 & 5.87 & 21.56 & 7.56 & 27.35 \\
\hline 60 & 39 & 1 & 15 & 3.12 & 10.23 & 5.21 & 19.32 & 6.42 & 23.36 \\
\hline 65 & 34 & 1 & 15 & 3 & 9.98 & 4.56 & 16.71 & 5.85 & 22.56 \\
\hline 70 & 29 & 1 & 15 & 2.85 & 9.79 & 4.3 & 15.65 & 5.36 & 20.12 \\
\hline 75 & 24 & 1 & 15 & 2.58 & 9.25 & 3.86 & 14.36 & 4.83 & 15.69 \\
\hline
\end{tabular}



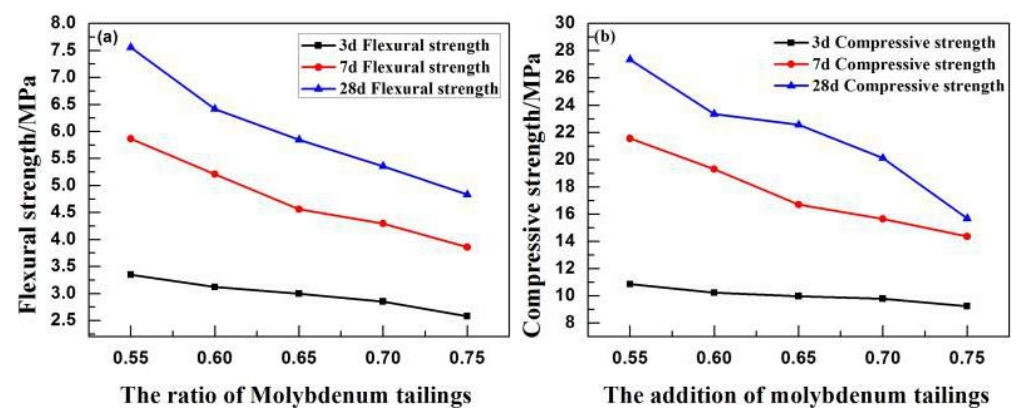

Fig.2 The effect of molybdenum tailings on mechanical properties:

(a) Flexural strength; (b) Compressive strength

When the addition of molybdenum tailings is $55 \%$, after $28 \mathrm{~d}$, the flexural strength and compressive strength are $7.56 \mathrm{MPa}$ and $27.35 \mathrm{MPa}$ respectively. Its mechanical properties meets MU25. When the addition of molybdenum tailings 60\% 70\%, the flexural strength and compressive strength are 5.36 6.42MPa and 20.12 23.36MPa respectively. Its mechanical properties meets MU20. When the addition of molybdenum tailings reach to $75 \%$, the flexural strength and compressive strength decrease to $4.83 \mathrm{MPa}$ and $15.69 \mathrm{MPa}$, and its mechanical properties meets MU15.

In the reaction process, the raw materials reacts with water, as show below. It formed CSH and $\mathrm{CAH}$. The particles of molybdenum tailing were bonded by $\mathrm{CSH}$ and $\mathrm{CAH}$, and formed skeletal structure. Hence, unfired brick attains mechanical strength. However, When the addition of molybdenum is larger, the gelled material is lacking in the unfired brick, so the skeletal structure is reduced, and the mechanical properties of unfired brick was decreased.In curing process, the reaction was occurred continuously. The curing time is more longer, the reaction is more full, so the properties of the brick is more better.

$$
\begin{aligned}
\mathrm{CaO}+\mathrm{H}_{2} \mathrm{O} & =\mathrm{Ca}(\mathrm{OH})_{2} \\
m \mathrm{Ca}(\mathrm{OH})_{2}+\mathrm{SiO}_{2}+x \mathrm{H}_{2} \mathrm{O} & =\mathrm{CaO} \cdot \mathrm{SiO}_{2} \cdot x \mathrm{H}_{2} \mathrm{O}(\mathrm{CSH}) \\
m \mathrm{Ca}(\mathrm{OH})_{2}+\mathrm{Al}_{2} \mathrm{O}_{3}+x \mathrm{H}_{2} \mathrm{O} & =\mathrm{CaO} \cdot \mathrm{Al}_{2} \mathrm{O}_{3} \cdot x \mathrm{H}_{2} \mathrm{O}(\mathrm{CAH})
\end{aligned}
$$

\section{The effect of ratio of molybdenum tailings to river sand on the properties of unfired Bricks}

Table 4 and Fig.3 show the effect of a mass ratio of molybdenum tailings to river sand on mechanical properties of unfired brick. It can be seen from Table 5 and fig. 4 that with a mass ratio of molybdenum to river sand increasing, the mechanical properties decreased firstly, and then increased. When the ratio is $1: 3.7$, the flexural strength and compressive strength are $5.01 \mathrm{MPa}$ and $20.86 \mathrm{Mpa}$ respectively at $28 \mathrm{~d}$. When the ratio is $1: 1$, the flexural strength and compressive strength decreased to 4.48MPa and $16.89 \mathrm{Mpa}$ respectively. When When the ratio is $1: 3.7$, the mechanical properties increased, the flexural strength and compressive strength increased to $4.96 \mathrm{MPa}$ and $19.95 \mathrm{Mpa}$ respectively. The reason is that the main chemical components of the molybdenum and sand is $\mathrm{SiO}_{2}$, but the other components are different and react with each other. It lead to the CSH and CAH

\begin{tabular}{|c|c|c|c|c|c|c|c|c|c|c|}
\hline \multicolumn{4}{|c|}{ The ratio of dry solids } & \multirow{2}{*}{$\begin{array}{c}\text { Water } \\
\text { addition } \\
\text { for } \\
\text { mixing/ } \\
\%\end{array}$} & \multicolumn{2}{|c|}{$\begin{array}{l}3 \mathrm{~d} \text { mechanical } \\
\text { properties/MPa }\end{array}$} & \multicolumn{2}{|c|}{$\begin{array}{l}7 \mathrm{~d} \text { mechanical } \\
\text { properties/MPa }\end{array}$} & \multicolumn{2}{|c|}{$\begin{array}{l}28 \mathrm{~d} \text { mechanical } \\
\text { properties/MPa }\end{array}$} \\
\hline $\begin{array}{c}\text { Cement } \\
\text { amount/ } \\
\%\end{array}$ & $\begin{array}{l}\text { Molybden- } \\
\text { um tailings/ } \\
\%\end{array}$ & $\begin{array}{c}\text { Sand } \\
\text { addition } \\
1 \% \\
\end{array}$ & $\begin{array}{l}\text { Accelerating } \\
\text { Admixture/\% }\end{array}$ & & $\begin{array}{l}\text { Flexural } \\
\text { strength }\end{array}$ & $\begin{array}{l}\text { Compr- } \\
\text { essive } \\
\text { strength }\end{array}$ & $\begin{array}{l}\text { Flexural } \\
\text { strength }\end{array}$ & $\begin{array}{l}\text { Compr- } \\
\text { essive } \\
\text { strength }\end{array}$ & $\begin{array}{l}\text { Flexural } \\
\text { strength }\end{array}$ & $\begin{array}{l}\text { Compr- } \\
\text { essive } \\
\text { strength }\end{array}$ \\
\hline 29 & 15 & 55 & 1 & 15 & 3.11 & 12.07 & 3.62 & 16.39 & 5.01 & 20.86 \\
\hline 29 & 25 & 45 & 1 & 15 & 2.65 & 12.74 & 3.53 & 18.82 & 4.98 & 19.22 \\
\hline 29 & 35 & 35 & 1 & 15 & 2.45 & 10.04 & 3.40 & 14.53 & 4.48 & 16.89 \\
\hline 29 & 45 & 25 & 1 & 15 & 2.72 & 8.99 & 3.58 & 15.76 & 4.51 & 18.10 \\
\hline 29 & 55 & 15 & 1 & 15 & 3.18 & 7.94 & 3.92 & 18.66 & 4.96 & 19.95 \\
\hline
\end{tabular}
decreased, so the mechanical properties is more smaller.

Table 4. Experimental results of a mass ratio of molybdenum tailings to river sand 

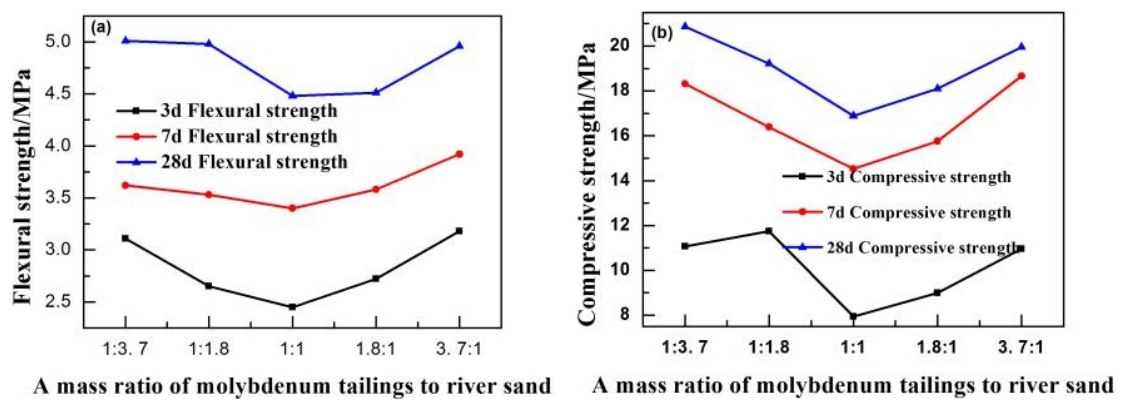

Fig.3 The effect of a mass ratio of molybdenum tailings to river sand on mechanical properties:

(a) Flexural strength; (b) Compressive strength

\section{The effect of silica powder on the properties of Baking-free Bricks}

Table 5 and Fig.4 show The effect of the addition of silica powder on mechanical properties of the unfired brick. With the addition of silica powder increased, the mechanical properties of unfired brick is decreased. When the addition of silica powder is $3 \%$, the flexural strength and compressive strength are $4.58 \mathrm{MPa}$ and $13.69 \mathrm{Mpa}$ respectively at $28 \mathrm{~d}$. When the addition of silica powder is $9 \%$, the flexural strength and compressive strength are $3.99 \mathrm{MPa}$ and $12.35 \mathrm{Mpa}$ respectively. When the addition of silica powder is $15 \%$, the flexural strength and compressive strength are $2.88 \mathrm{MPa}$ and 9.64Mpa respectively.

Table 5. Experimental results of the addition of silica powder

\begin{tabular}{|c|c|c|c|c|c|c|c|c|c|c|}
\hline \multicolumn{4}{|c|}{ The ratio of dry solids } & \multirow{2}{*}{$\begin{array}{l}\text { Water } \\
\text { addition } \\
\text { for } \\
\text { mixing/ } \\
\%\end{array}$} & \multicolumn{2}{|c|}{$\begin{array}{l}3 \mathrm{~d} \text { mechanical } \\
\text { properties } / \mathrm{MPa}\end{array}$} & \multicolumn{2}{|c|}{$\begin{array}{l}7 \mathrm{~d} \text { mechanical } \\
\text { properties/MPa }\end{array}$} & \multicolumn{2}{|c|}{$\begin{array}{l}\text { 28dmechanical } \\
\text { properties/MPa }\end{array}$} \\
\hline $\begin{array}{c}\text { Cement } \\
\text { amount/ } \\
\%\end{array}$ & $\begin{array}{c}\text { Molybden- } \\
\text { um tailings/ } \\
\%\end{array}$ & $\begin{array}{c}\text { Silica } \\
\text { powder/ } \\
\% \\
\end{array}$ & $\begin{array}{c}\text { Accelerating } \\
\text { Admixture/\% }\end{array}$ & & $\begin{array}{l}\text { Flexural } \\
\text { strength }\end{array}$ & $\begin{array}{l}\text { Compr- } \\
\text { essive } \\
\text { strength }\end{array}$ & $\begin{array}{l}\text { Flexural } \\
\text { strength }\end{array}$ & $\begin{array}{l}\text { Compr- } \\
\text { essive } \\
\text { strength } \\
\end{array}$ & $\begin{array}{l}\text { Flexural } \\
\text { strength }\end{array}$ & $\begin{array}{l}\text { Compr- } \\
\text { essive } \\
\text { strength }\end{array}$ \\
\hline 29 & 67 & 3 & 1 & 15 & 1.48 & 2.95 & 3.87 & 10.21 & 4.26 & 13.69 \\
\hline 29 & 64 & 6 & 1 & 15 & 1.5 & 3.0 & 3.54 & 9.79 & 4.08 & 13.25 \\
\hline 29 & 61 & 9 & 1 & 20 & 1.32 & 2.5 & 3.05 & 8.56 & 3.99 & 12.35 \\
\hline 29 & 8 & 12 & 1 & 20 & 0.82 & 1.69 & 2.12 & 5.64 & 3.16 & 9.89 \\
\hline \multirow[t]{3}{*}{29} & 55 & 15 & 1 & 22 & 0.7 & 1.8 & 1.69 & 5.54 & 2.88 & 9.64 \\
\hline & & $\underbrace{5}$ & & $\begin{array}{l}\text { exural strength } \\
\text { exural strength } \\
\text { lexural strength }\end{array}$ & 政 ${ }^{14}$ & & & $\begin{array}{l}\text { e strength } \\
\text { e strength } \\
\text { e strength }\end{array}$ & & \\
\hline & & & 0.06 & 0.15 & 0.0 & 0.06 & $\begin{array}{ll} & \\
0.09 & 0.12\end{array}$ & 0.15 & & \\
\hline
\end{tabular}

Fig.4 The effect of the addition of silica powder on mechanical properties:

(a) Flexural strength; (b) Compressive strength

\section{Conclusions}

With the addition of molybdenum tailings increased, the mechanical properties of the unfired brick was decreased. When the addition of molybdenum tailings is below $75 \%$, the flexural strength and compressive strengh are above 4.83MPa and 15.69MPa respectively, it meets MU15 standard. With the ratio molybdenum tailings to river sand increasing, the mechanical properties decreased firstly, and then increased. The mechanical properties of unfired brick is decreased with increasing of the silica powder.

\section{Acknowledgements}

This work was financially supported by the Plan Projects of Science and technology as a whole by Shaanxi Province(2012KTDZ02-02-01) and Funded by the Research Fund of Shaanxi Key Laboratory of Comprehensive Utilization of Tailings Resources(Shangluo University)(2014SKY- 
WK013), and the Scientific Projects of Shangluo University(15SKY004).

\section{Reference}

[1] Meng Zenhui, Ni Wen, Zhang Yuyan. Current state of ore tailings reusing and its future development in China[J]. China Mine Engineering, 2010, 39(5): 4-9.

[2]Yin Hongfeng, Xia Lilong, Ren Yun, et al. Investigation on Making Building Bricks with Tailings of Hanxing Iron Mine[J]. METAL MINE, 2006, (356): 79-81.

[3] Feng Qiming, Wang Weiqing, Zhang Bolian, et al. Research on Technics of Lightweight Bakingfree Brick made of Lead-Zinc Ore Tailings from Qinghai Province[J]. Non-Metallic Mines, 2011, 34(3): 6-8.

[4] Yanzhen Yu, Lipan Guan, Yan Feng, et al. Study on preparing municipal sludge unfired bricks[C]. Proceedings of Beijing 2009 International Environmental Technology Conference, 2009, Beijing: 578-584. 